\title{
Sequential Voicing in Old Japanese
}

\author{
Wenchao Li \\ School of International Studies, Zhejiang University \\ Hangzhou, China \\ E-mail: widelia@zju.edu.cn
}

Received: September 3, 2020 Accepted: October 21, 2020 Published: October 27, 2020

doi:10.5296/ijl.v12i5.17733

URL: https://doi.org/10.5296/ijl.v12i5.17733

\begin{abstract}
This study tackles sequential voicing in Old Japanese with a focus on three matters: (a) the interaction of the eight vowels and aspirated consonants; (b) the association of the written system and sequential voicing; and (c) the interaction between the combinationality of each constituent and sequential voicing. Four hundred and seventy-two compound nouns of Old Japanese were collected from the corpus 'The Japanese Lexicon: A Rendaku Encyclopedia' by NINJAL. The findings reveal that (i) $/ \mathrm{k} /$ has the largest token number of sequential voicing and $/ \mathrm{p} /$ has the second largest token number, followed by $/ \mathrm{s} /$ and $/ \mathrm{t} /$; (ii) regarding the eight vowels $/ \mathrm{a} /, / \mathrm{e}_{1} /, / \mathrm{e}_{2} /, / \mathrm{i}_{1} /, / \mathrm{i}_{2} /, / \mathrm{o}_{1} /, / \mathrm{o}_{2} /$ and $/ \mathrm{u} /, / \mathrm{a} /$ is most likely to form a $\left[\mathrm{N}_{1}-\mathrm{N}_{2}\right]$ whose initial consonant is $/ \mathrm{k} /, / \mathrm{p} /$ and $/ \mathrm{t} /$. It is not likely for the vowel $/ \mathrm{a} /$ to invite a voiced ' $/ \mathrm{s} /$-initial' $\mathrm{N}_{1}{ }^{\prime} ; / \mathrm{o}_{1} /$ and $/ \mathrm{o}_{2} /$ are both likely to combine with a voiced consonant $/ \mathrm{k} /$; $/ \mathrm{t} /$ and are less likely to yield a voiced $/ \mathrm{s} / ; / \mathrm{e}_{1} /$ is more likely to invite a voiced consonant than $/ \mathrm{e}_{2} /$, but $/ \mathrm{e}_{1} /$ does not invite a voiced $/ \mathrm{p} / ; / \mathrm{e}_{2} /$ does not yield a voiced $/ \mathrm{s} / ;$ and $/ \mathrm{i}_{1} /$ is likely to take a voiced consonant than $/ \mathrm{i}_{2} / . / \mathrm{k} /$ and $/ \mathrm{t} /$ are the two consonants that are most likely to be voiced when forming a $\mathrm{N}-\mathrm{N}$ with $\mathrm{N}_{1}$ ends with $/ \mathrm{i}_{1} / . / \mathrm{i}_{2} /$ does not invite a voiced $/ \mathrm{p} /, / \mathrm{s} /$ or $/ \mathrm{t} / ; / \mathrm{u} /$ never results in a voiced /s/; (iii) there is a split in the characters that renders a voiced phoneme or an unvoiced phoneme; and (iv) the semantic relationship of $\mathrm{N}_{1}$ and $\mathrm{N}_{2}$ in $\left[\mathrm{N}_{1}-\mathrm{N}_{2}\right]$ that bears sequential voicing is of six types, of which the most frequent relationship of $N_{1}$ and $N_{2}$ is [Modifier $\mathrm{N}_{2}$ ]. The [prefix- $\mathrm{N}_{2}$ ] construction is not subject to sequential voicing.
\end{abstract}

Keywords: Sequential voicing, Old Japanese, Vowels, Consonant alternation, Semantic relation

\section{Introduction}

In Modern Japanese, nominal compounds $\left[\mathrm{N}_{1}-\mathrm{N}_{2}\right]$ fall into seven subtypes regarding the semantic relation between $\mathrm{N}_{1}$ and $\mathrm{N}_{2}$, as follows: 


\section{1) Macrothink}

(1) a. Object + Tran. ${ }_{\text {Cons.; }}$;

b. Instrument + Tran. CoNJ. $_{\text {; }}$

c. Modifier - Tran. ${ }_{\text {Cons.; }}$;

d. Place - Tran.cons.;

e. Method - Tran.cons.;

f. $\quad$ Cause - Tran.cons.;

g. Subject - Tran. cons.

Among these variations, sequential voicing is only subject to the $\left[\mathrm{N}_{\text {OBJECT }}-\mathrm{N}_{\text {TRAN.conj.] }}\right.$ type. Sequential voicing is a phonological phenomenon: during the process of forming a nominal compound, the second constituents $\left(\mathrm{N}_{2}\right)$ rendered by aspirated consonants $/ \mathrm{k} /, / \mathrm{s} /, \mathrm{h} / \mathrm{and} / \mathrm{t} /$ become voiced.

(2) The consonants that are likely to be voiced (Kubozono 1999):

h. $\quad / \mathrm{k} / \rightarrow / \mathrm{g} /$

i. $\quad / \mathrm{s} / \rightarrow / \mathrm{z} /, / 6 / \rightarrow /(\mathrm{d}) \mathrm{z} / ;$

j. $\quad / \mathrm{t} / \rightarrow / \mathrm{d} /, / \mathrm{t} 6 / \rightarrow /(\mathrm{d}) \mathrm{z} /, / \mathrm{ts} / \rightarrow /(\mathrm{d}) \mathrm{z} / ;$

k. $/ \mathrm{h} /, / \mathrm{ç} /, / \phi / \rightarrow / \mathrm{b} /$.

(3) Provides an illustration of this consonant alternation:

(3) Illustrations of consonant alternation:
a. kaeru 'frog'
$\rightarrow \quad$ ama 'rain' + kaeru
amagaeru 'tree frog'
b. tsubushi 'crush'
$\rightarrow \quad$ jikan 'time' + tsubushi
jikantsubushi 'time-killing'
c. tsukuri 'make something' $\rightarrow \quad$ te 'hand' + tsukuri
tedukuri 'hand-made'
d. $k o$ 'child'
oya 'parent' + ko
oyako 'parent + child'

Sequential voicing has been studied intensively in Japanese linguistics since 1767. This boom was kicked off by the publication of Motoori Norinaga (1767-98), Kojiki den, 'A study on kojiki'. Many scholars from different backgrounds have dedicated works to the constraints on sequential voicing, e.g. Motoori, Lyman (1894), Sakurai (1972), Kindaichi (1976), Akinaga (1977), Morita (1977), Okumura (1980), Yamaguchi (1988), Ohta (1998), etc. This line of research tackles the phenomenon from a phonological perspective. Motoori Norinaga demonstrated that, when N2 already contains a voiced consonant, sequential voicing should be avoided. Later, American linguist Lyman proposed similar observations in 1894.

The constraints are not limited to phonology or morphology, but extend to syntax: in other words, when N1 is the subject or object of N2, sequential voicing does not occur, cf. (4). 


$\begin{array}{lclll}\text { (4) a. Gohan } & \text { o } & \text { taku } & \rightarrow & \text { gohantaki } \\ \text { food } & \text { ACC } & \text { cook } & & \text { food cooking } \\ \text { b. yuki } & \text { ga } & \text { furu } & \rightarrow & \text { yukifuri } \\ \text { snow } & \text { NOM } & \text { fall } & & \text { snow falling }\end{array}$

Another pathway comes from lexical semanticians, inspiring a morpho-syntactic approach. Representative work includes OHtsu (1980) on three-word compound nouns, indicating that, in a $\left[\mathrm{N}_{1}-\mathrm{N}_{2}-\mathrm{N}_{3}\right]$ compound, only the [left-headed $\left.\mathrm{N}-\mathrm{N}\right]$, i.e. [ $\left.\left[\mathrm{N}_{1}-\mathrm{N}_{2}\right]-\mathrm{N}_{3}\right]$, pattern accepts sequential voicing. This view is confirmed by Ito and Mester (1986), Satoo (1989) and Takayama (2001).

A different view comes from Ishizuka (1801), who noted that, in Old Japanese, when there is a voiced consonant in the first noun $\left(\mathrm{N}_{1}\right)$, the other nouns will not be voiced. Further diachronic work includes Lv (2014), who carried out an investigation on the sequential voicing regarding Sino-Japanese: ' $\sim$ san', ' $\sim$ sei', ' $\sim$ hon'.

Another line of research bears relevance to the present study, arguing in favour of semantic factors, i.e. the semantic relationships between $\mathrm{N}_{1}$ and $\mathrm{N}_{2}$. Representative work includes Ito (2008). Three constraints are proposed, as follows:

(5) Constraints on sequential voicing

a. Loanwords, Sino-Japanese (Note 1), compound verbs and onomatopoeia are ruled out;

b. When N1 and N2 are assigned to a coordinate relation, sequential voicing can be avoided;

c. When $\mathrm{N}_{1}$ behaves as a modifier to $\mathrm{N}_{2}$, the compound noun will avoid sequential voicing.

Figure 1 summarises the previous streams that contribute to the study of sequential voicing.

- Synchronic perspective

Phonological constraints $(1767,1894)$

$\downarrow$

Morpho-syntactic approach $(1980,1986,1989,2001)$

$\downarrow$

Semantic point of view (Ito 2008)

- Diachronic perspective: Ishizuka (1801), Lv (2014)

Figure 1. The streams that contributes to the study of sequential voicing

Although previous work has contributed a good deal to the phonligcal, morphological and semantic phenomena of sequential voicing, there is room for further attention. 


\subsection{Sequential Voicing in Old Japanese (7th-8th Century AD.)}

Old Japanese is a dead language used in the Asuka and Nara periods. Essentially, its vowel system differs a good deal from Modern Japanese. The vowel harmony presented in Modern Altaic language families is displayed in Old Japanese. Unlike Modern Japanese, which contains five vowels, /a/, /i/, / / /, /e/ and /o/, there are two tyoes of the vowels $/ \mathrm{i} /$, /e/ and /o/, one known as koo-rui (type $\mathrm{A}: / \mathrm{i}_{1} / ; / \mathrm{e}_{1} / ; / \mathrm{o}_{1} /$ ) and one known as otsu-rui (type $\mathrm{B}$ : $/ \mathrm{i}_{2} / ; / \mathrm{e}_{2} / ; / \mathrm{o}_{2} /$. As a result, Old Japanese has eight vowels: $/ \mathrm{a} /, / \mathrm{e}_{1} /, / \mathrm{e}_{2} /, / \mathrm{i}_{1} /, / \mathrm{i}_{2} /, / \mathrm{o}_{1} /, / \mathrm{o}_{2} /$ and $/ \mathrm{u} / \mathrm{cf}$. Bjarke Frellesvig 2010). Given this, the present study aims to pin down how the unique vowel system in Old Japanese interacts with consonant alternation (from aspirated to voiced). Moreover, Old Japanese features serial word construction. Therefore, this study wishes to confirm whether there is a patterning of the consonant alternation, such as when the serial noun combination is assigned to $\left[\left[\mathrm{N}_{1}-\mathrm{N}_{2}\right]-\mathrm{N}_{3}\right]$ : as Ohtsu (1980) put it, it is likely to have sequential voicing.

\subsection{Writing System in Old Japanese}

In Early Old Japanese, the script hentai-kanbun, 'variant Chinese', is used. the conjugations are rendered by Chinese characters: the gerund form is conveyed by $\boldsymbol{\Xi}$ ' $て$ '; the provisional form is denoted by 婆 ‘ば’; and the adnominal form of the ichi dan conjugation is rendered by the Chinese character 流 ‘る’. A second script in the Early Nara Period is Junsei-kanbun, 'purely classical Chinese', which is deemed to have been the official language in the Nara Period. In Late Old Japanese, logographic writing and phonographic writing were both borrowed. Phonographic writing is likely to render nouns, verbs and adjectives and logographic writing tends to convey case particles. In essence, a non-voicing consonant and a voiced consonant are written in different characters. For instance, 加 represents the non-vocal syllable 'ka', whilst 我 represents the voiced syllable 'ga'. Therefore, this study aims to uncover how the writing script interacted with consonant alternation.

The data is drawn from the 'Old Japanese Rendaku Database (version 1.0)'. It is the product of collaboration between the Rendaku Encyclopedia project carried out at the National Institute for Japanese Language and Linguistics (NINJAL) and the Oxford Corpus of Old Japanese (OCOJ) project carried out at the University of Oxford.

This paper is structured as follows. Section 1 summaries past work on sequential voicing. Section 2 presents quantified data, tackling the interactions of the alternation possibilities of vowels and consonants. Section 3 turns to the scripts that represent voiced and non-voiced consonants. Section 4 delves into the combinationality (or the lexicalisation degree) of the multiple-noun constructions that incorporate sequential voicing. Section 5 highlights the results and concludes the paper. 


\section{Macrothink

\section{The Interactions of Vowels and the Voiced Consonants}

As sequential voicing only takes place with the aspirated consonants, this study will focus on four consonants, $/ \mathrm{k} /, / \mathrm{p} /, / \mathrm{s} /$ and $/ \mathrm{t} /$, examining the interaction between them and the eight vowels $/ a /, / e_{1} /, / e_{2} /, / i_{1} /, / i_{2} /, / o_{1} /, / o_{2} /$ and $/ \mathrm{u} /$.

(6) a. Consonants

$/ \mathrm{k} /, / \mathrm{p} /, / \mathrm{s} /, / \mathrm{t} /$

b. Vowels

$/ \mathrm{a} /, / \mathrm{e}_{1} /, / \mathrm{e}_{2} /, / \mathrm{i}_{1} /, / \mathrm{i}_{2} /, / \mathrm{o}_{1} /, / \mathrm{o}_{2} /, / \mathrm{u} /$

(7)- (12) provides illustrations of sequential voicing regarding each vowel and consonant in Old Japanese.

(7) $/ 0_{1} /+$ a voiced consonant

e.g. 琴 koto + 赫 kami $\rightarrow$ kotogami

(8) $/ \mathbf{o}_{2} /+$ a voiced consonant

e.g. 野 nwo + 蒜 piru $\rightarrow$ nwobiru

(9) $/ \mathbf{e}_{1} /+\mathbf{a}$ voiced consonant

e.g. 朝寝 asa-ne + 髪 $\mathrm{kami} \rightarrow$ asanegami

(10) $/ \mathbf{e}_{2} /+\mathbf{a}$ voiced consonant

e.g. 八重 ya-pye + 垣 kaki $\rightarrow$ yapyegaki

(11) /a/ + a voiced consonant

e.g. 下 shita + 恋 kwopwi $\rightarrow$ sitagwopwi

(12) $/ \mathbf{u} /$ + a voiced consonant

e.g. 松 matsu + 原 hara $\rightarrow$ matsubara

Four hundred and seventy-two compound nouns of Old Japanese were collected from the corpus 'The Japanese Lexicon: A Rendaku Encyclopedia' by NINJAL. A search on the database revealed that the sequential voicing of the aspirated consonants distribute as follows: the compound nouns for which $\mathrm{N}_{2}$ begins with the consonant $/ \mathrm{k} /$ have the largest token number of sequential voicing; the compound nouns for which $\mathrm{N}_{2}$ begins with the consonant $/ \mathrm{p} /$ have the second largest token number (126); the compound nouns for which $\mathrm{N}_{2}$ begins 
with the consonant /s/ are attributed 61 tokens; and 114 tokens go to the compound nouns for which $\mathrm{N}_{2}$ begins with the consonant /t/. Moreover, this study calculated the distribution of $\mathrm{N}_{1}$ ending with the vowels $/ \mathrm{a} /, / \mathrm{e}_{1} /, / \mathrm{e}_{2} /, / \mathrm{i}_{1} /, / \mathrm{i}_{2} /, / \mathrm{o}_{1} /, / \mathrm{o}_{2} /$ and $/ \mathrm{u} /$. The findings are summarised in Table 1.

Table 1. Vowels and consonant alternation in Old Japanese

\begin{tabular}{lllllllll}
\hline Vowels & $\begin{array}{l}/ \mathrm{k} / \text { not } \\
\text { voiced }\end{array}$ & $\begin{array}{l}/ \mathrm{k} / \\
\text { voiced }\end{array}$ & $\begin{array}{l}/ p / \text { not } \\
\text { voiced }\end{array}$ & $\begin{array}{l}/ p / \\
\text { voiced }\end{array}$ & $\begin{array}{l}/ s / \text { not } \\
\text { voiced }\end{array}$ & $\begin{array}{l}/ s / \\
\text { voiced }\end{array}$ & $\begin{array}{l}/ t / \text { not } \\
\text { voiced }\end{array}$ & voiced \\
\hline$/ \mathrm{o}_{1} /$ & 20 & 9 & 16 & 4 & 6 & 1 & 11 & 6 \\
\hline$/ \mathrm{o}_{2} /$ & 10 & 7 & 2 & 3 & 4 & 1 & 3 & 5 \\
\hline$/ \mathrm{e}_{1} /$ & 7 & 11 & 3 & 0 & 2 & 1 & 6 & 2 \\
\hline$/ \mathrm{e}_{2} /$ & 5 & 3 & 0 & 1 & 0 & 0 & 2 & 1 \\
\hline$/ \mathrm{i}_{1} /$ & 23 & 11 & 19 & 9 & 6 & 1 & 13 & 10 \\
\hline$/ \mathrm{i}{ }_{2} /$ & 3 & 5 & 0 & 0 & 0 & 0 & 0 & 0 \\
\hline$/ \mathrm{a} /$ & 49 & 24 & 34 & 19 & 39 & 1 & 35 & 16 \\
\hline$/ \mathrm{u} /$ & 16 & 6 & 11 & 4 & 8 & 0 & 6 & 4 \\
\hline
\end{tabular}

A more detailed picture of the vowels and their interaction with the possibilities of sequential voicing is summarised in Figure 2.

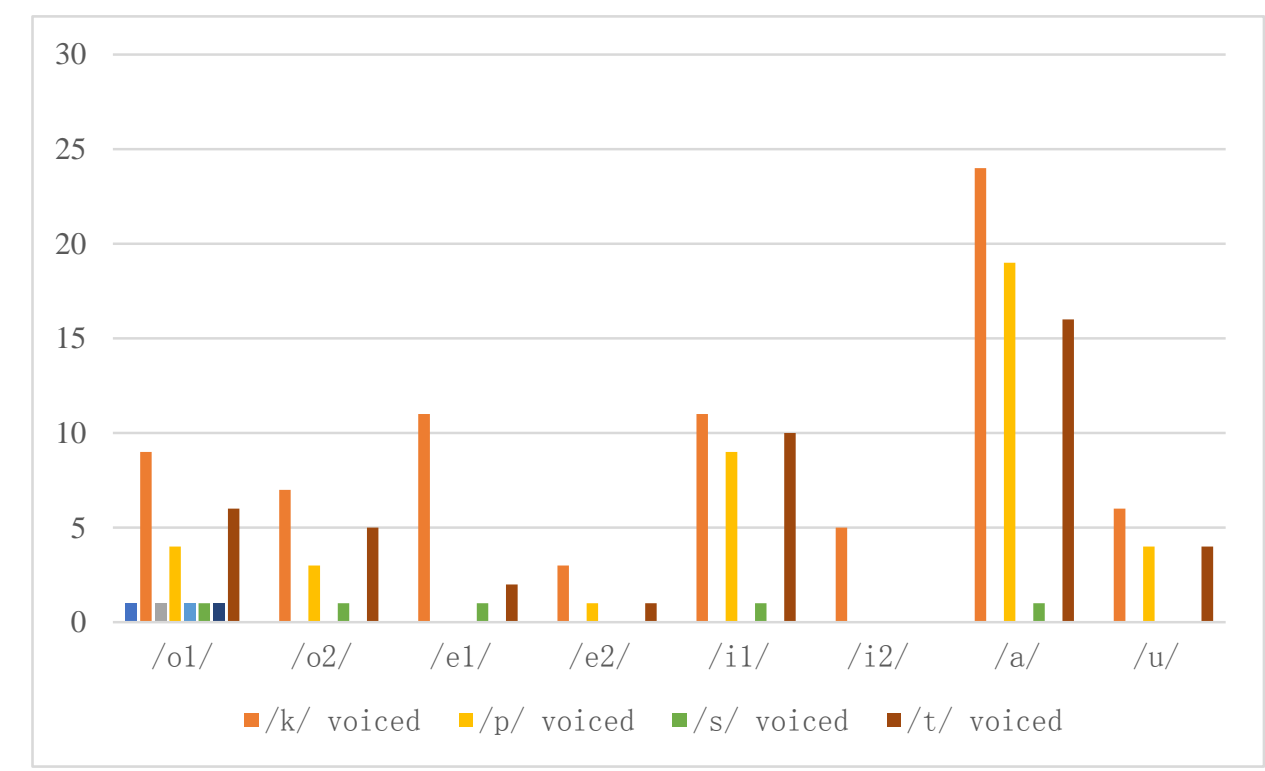

Figure 2. The interaction of vowels and consonant alternation in Old Japanese

Figure 2 reveals the following.

(a) The vowel /a/ is most likely to form a compound noun for which $\mathrm{N}_{2}$ begins with the consonant $/ \mathrm{k} /, / \mathrm{p} /$ or $/ \mathrm{t} /$. It is not likely for the vowel $/ \mathrm{a} /$ to invite a ' $/ \mathrm{s} /$-initial $\mathrm{N}_{1}$ ' becoming voiced.

(b) $/ \mathrm{o}_{1} /$ and $/ \mathrm{o}_{2} /$ present a similar picture: both are likely to give rise to sequential voicing regarding the consonant $/ \mathrm{k} /$ and $/ \mathrm{t} /$ and less likely to yield sequential voicing regarding $/ \mathrm{s} /$. 


\section{Macrothink}

International Journal of Linguistics

ISSN 1948-5425 2020, Vol. 12, No. 5

(c) For $/ \mathrm{e}_{1} /$ and $/ \mathrm{e}_{2} /$, the compound nouns for which $\mathrm{N}_{1}$ ends with the vowel $/ \mathrm{e}_{1} /$ are likely to have a voiced consonant; the compound nouns for which $\mathrm{N}_{1}$ ends with the vowel $/ \mathrm{e}_{2} /$ are not likely to. $/ \mathrm{e}_{1} /$ does not invite sequential voicing when forming a compound noun when $\mathrm{N}_{1}$ begins with the consonant $/ \mathrm{p} /$. $_{2} / \mathrm{e}_{2} /$ does not yield sequential voicing when forming a compound noun when $\mathrm{N}_{2}$ begins with the consonant/s/.

(d) Among $/ i_{1} /$ and $/ i_{2} /, N_{1}$ that ends with the vowel $/ i_{1} /$ appears more likely to take a voiced consonant than $\mathrm{N}_{1}$ ending with $/ \mathrm{i}_{2} / \mathrm{k} /$ and $/ \mathrm{t} /$ are the two consonants most likely to be voiced when forming a N-N with $\mathrm{N}_{1}$ ending with $/ \mathrm{i}_{1} /$. No data suggests that $/ \mathrm{i}_{2} /$ would give rise to sequential voicing when forming a compound noun for which $\mathrm{N}_{1}$ begins with /p/, /s/ or $/ \mathrm{t} /$.

(e) $/ \mathrm{u} /$ never results in sequential voicing when forming a compound noun for which $\mathrm{N}_{1}$ begins with /s/.

\section{Writings and Sequential Voicing}

Having highlighted the phonological features of sequential voicing in Old Japanese, we are now in the position to explore what the writing script has to do with the phonological matter. This study examined the 472 data entries and formed the following picture: there are different characters rendering a voiced phoneme or an unvoiced phoneme.

The opening characters differ according to whether they convey a voiced phoneme or not.

\section{(13). /k/-phoneme-initial characters}

- 垣, 上, 鴨, 金, 川, 柄, 形, 茅, 笥, 薦, 頃, 衣, 言, 事, 隈, 雲, 杭, 草, 子,

駒 and 恋 can render both a voiced and an unvoiced phoneme.

- 貝, 桑, 酒 and 霧 seem solely to render a voiced phoneme.

- 樫，風，国 and 木 seem solely to convey an unvoiced phoneme.

Table 2. /k/ phoneme initial characters' phonological role

\begin{tabular}{|c|c|c|c|}
\hline Writings & $\begin{array}{l}\text { Voiced } \\
\text { phoneme }\end{array}$ & $\begin{array}{l}\text { Unvoiced } \\
\text { phoneme }\end{array}$ & $\begin{array}{l}\text { Both voiced and } \\
\text { unvoiced phoneme }\end{array}$ \\
\hline $\begin{array}{l}\text { 垣, 上, 鴨, 金, 川, 柄, } \\
\text { 形, 茅, 笥, 薦, 頃, 衣, } \\
\text { 言, 事, 隈, 雲, 杭, 草, } \\
\text { 子, 駒, 恋 }\end{array}$ & & & $\bigcirc$ \\
\hline 貝，桑，酒，霧， & 0 & $\times$ & \\
\hline 樫，風，国，木 & $\times$ & $\bigcirc$ & \\
\hline
\end{tabular}


(14). /p/ phoneme initial characters

- 花, 原, 柱, 機, 人 and 船 can render a voiced and an unvoiced phoneme.

- 葉, 吹, 袋 and 含 seem always to render a voiced phoneme.

- 橋, 瓮, 日, 辺 and 重 seem only to convey an unvoiced phoneme.

Table 3. /p/-phoneme-initial characters' phonological role

\begin{tabular}{llll}
\hline Writings & $\begin{array}{l}\text { Voiced } \\
\text { phoneme }\end{array}$ & $\begin{array}{l}\text { Unvoiced } \\
\text { phoneme }\end{array}$ & $\begin{array}{l}\text { Both voiced and } \\
\text { unvoiced phoneme }\end{array}$ \\
\hline 花, 原, 柱, 機, 人, 船 & & & $\bigcirc$ \\
\hline 葉, 吹, 袋, 食 & $\bigcirc$ & $\times$ & \\
\hline 橋, 瓮, 日, 辺, 重 & $\times$ & $\bigcirc$ & \\
\hline
\end{tabular}

(15). /s/-phoneme-initial characters

- 瀬, 白 can render a voiced and a unvoiced phoneme.

- No character seems to always render a voiced phoneme.

- 更, 兄, 数, 島, 霜, 潮, 代, 獣, 洲, 菅, 薄, 十, 麻 seem to solely convey an unvoiced phoneme.

Table 4. /k/ phoneme initial characters' phonological role

\begin{tabular}{llll}
\hline Writings & $\begin{array}{l}\text { Voiced } \\
\text { phoneme }\end{array}$ & $\begin{array}{l}\text { Unvoiced } \\
\text { phoneme }\end{array}$ & $\begin{array}{l}\text { Both voiced and } \\
\text { unvoiced phoneme }\end{array}$ \\
\hline 瀬, 白, & & & $\bigcirc$ \\
\hline & $\bigcirc$ & $\times$ & \\
\hline $\begin{array}{l}\text { 更, 兄, 数, 島, 霜, 潮, } \\
\text { 代, 獣, 洲, 菅, 薄 }\end{array}$ & & $\bigcirc$ & \\
\hline
\end{tabular}

(16). /t/ phoneme initial characters

- 玉, 手, 父, 鳥, 津 and 妻 can render a voiced and an unvoiced phoneme.

- 竹 and 処 seem solely to render a voiced phoneme.

- 栲, 大刀，橘，時，月，苞，露 and 戸 seem solely to convey an unvoiced phoneme. 


\section{1) Macrothink}

Table 5. /k/ phoneme initial characters' phonological role

\begin{tabular}{llll}
\hline Writings & $\begin{array}{l}\text { Voiced } \\
\text { phoneme }\end{array}$ & $\begin{array}{l}\text { Unvoiced } \\
\text { phoneme }\end{array}$ & $\begin{array}{l}\text { Both } \\
\text { unvoiced phoneme }\end{array}$ \\
\hline 玉, 手, 父, 鳥, 津, 妻 & & & $\bigcirc$ \\
\hline 竹, 処 & $\bigcirc$ & $\times$ & \\
\hline $\begin{array}{l}\text { 楛, 大刀, 橘, 時, 月, } \\
\text { 苞, 露, 戸 }\end{array}$ & $\bigcirc$ & $\bigcirc$ & \\
\hline
\end{tabular}

\section{Sequential Voicing and Lexical Semantics}

Drawing on the restrictions of sequential voicing highlighted above, this section moves on to consider what the combinationality of the two constituents might have to do with sequential voicing. This is explained by the following: in Old Japanese, serial verb constructions and serial noun combinations are extensively employed.

In the database, about 136 entries present sequential voicing (an appendix is provided at the end of the text). The semantic relations between the $\mathrm{N}_{1}$ and $\mathrm{N}_{2}$ in the serial noun constructions fall into six types, as follows.

(17) The semantic relation between the $\mathbf{N}_{1}$ and $\mathbf{N}_{\mathbf{2}}$ in Old Japanese

(I). [Modifier $-\mathrm{N}_{2}$ ]: $\mathrm{N}_{1}$ is the modifier of $\mathrm{N}_{2}$;

(II). [Possession $-\mathrm{N}_{2}$ ]: $\mathrm{N}_{1}$ is the possession of $\mathrm{N}_{2}$;

(III). [Cause $-\mathrm{N}_{2}$ ]: $\mathrm{N}_{1}$ is the cause of $\mathrm{N}_{2}$;

(IV). [Subject-object]: $\mathrm{N}_{1}$ is subject and $\mathrm{N}_{2}$ is the object;

(V). [Verb-object]: $\mathrm{N}_{1}$ is verb and $\mathrm{N}_{2}$ is the object;

(VI). $\mathrm{N}_{1}$ and $\mathrm{N}_{2}$ are reduplicated words.

The first type, (I). [Modifier $-\mathrm{N}_{2}$ ], has six subtypes, as shown in (18).

(18) Type I [Modifier $-\mathbf{N}_{2}$ ] has six subtypes

a. N1 indicates characteristics of N2;

b. $\mathrm{N}_{1}$ indicates the quantity of $\mathrm{N}_{2}$;

c. $\mathrm{N}_{1}$ indicates the profession of $\mathrm{N}_{2}$;

d. $\mathrm{N}_{1}$ indicates the place of $\mathrm{N}_{2}$;

e. $\mathrm{N}_{1}$ indicates the usage of $\mathrm{N}_{2}$;

f. $\mathrm{N}_{1}$ indicates the time of $\mathrm{N}_{2}$.

The tokens of each type, along with illustrations, are provided in Table 6. 
Table 6. The semantic relation between the $\mathrm{N}_{1}$ and $\mathrm{N}_{2}$ of the $\mathrm{N}-\mathrm{N}$ that bears sequential voicing

\begin{tabular}{lll}
\hline $\begin{array}{l}\text { The semantic relationship between } \\
N 1 \text { and } N 2\end{array}$ & & \\
\begin{tabular}{lll} 
(I) $\quad$ [Modifier $\left.-\mathrm{N}_{2}\right]$ : & & \\
\hline a. $\quad$ Modifier (characteristic) $-\mathrm{N}_{2}$ & 101 & 吉事 yo-goto 'good things' \\
\hline b. Modifier (quantity) $-\mathrm{N}_{2}$ & 6 & 八節 ya-bu 'many nodes' \\
\hline c. Modifier (profession) $-\mathrm{N}_{2}$ & 2 & 海人船 ama-bune 'fisherman boat' \\
\hline d. Modifier (time) $-\mathrm{N}_{2}$ & 5 & 夕月夜 yupu-toku-ywo 'evening moon' \\
\hline e. Modifier (place) $-\mathrm{N}_{2}$ & 15 & 宮柱 miya-bashira 'palace pillar' \\
\hline f. Modifier (usage) $-\mathrm{N}_{2}$ & 7 & 針袋 hari-bukuro 'needle bag' \\
\hline (II) Possession $-\mathrm{N}_{2}$ & 3 & 己妻 ono-duma 'own spouse' \\
\hline (III) Cause $-\mathrm{N}_{2}$ & 1 & 朝寝髮 asane-gami 'morning-sleep hair' \\
\hline (IV) Subject-object & 1 & 葉広 pa-biro 'leaf spreading' \\
\hline (V) Verb-object & 2 & 語言 katari-goto 'narrated words' \\
\hline (VI)Reduplicated word & 3 & 頃頃 koro+goro 'nowadays' \\
\hline
\end{tabular}
\end{tabular}

As Table 6 suggests, the most frequent relationship of $N_{1}$ and $N_{2}$ is [Modifier $-N_{2}$ ] (136 tokens). The second largest number of tokens is attributed to [Possession $-\mathrm{N}_{2}$ ] and [Reduplicated word]. [Verb-object] has the third largest applicability. Moreover, we note the following additional results: [Cause $-\mathrm{N}_{2}$ ] (1 token) and [Subject-object] (1 token).

Furthermore, sequential voicing appears to be linked to the degree of combinationality of the multiple constituent. when the two constituents are tightly combined or being lexicalised into one word, it is likely that the second constituent would be voiced, as shown in the [Modifier $\mathrm{N}_{2}$ ] type. If, however, the first constituent acts as a prefix, sequential voicing will not be yielded.

(19) [Prefix $\left.-\mathrm{N}_{2}\right]: \mathrm{N}_{2}$ is unlikely to be voiced

$$
\begin{aligned}
& \text { e.g. 真 }+ \text { 梶 } \rightarrow \bigcirc \text { ma-kadi 'Chinese mulberry'; xma-gadi } \\
& \text { 御 }+ \text { 門 } \rightarrow \bigcirc \text { mi-kadwo 'the honoured gate'; xmi-gadwo } \\
& \text { 真 }+ \text { 櫂 } \rightarrow \bigcirc \text { ma-kai 'paired oars'; × ma-gai }
\end{aligned}
$$

Why $\mathrm{N}_{2}$ in [Prefix $-\mathrm{N}_{2}$ ] does not yield sequential voicing is probably explained by the degree of lexicalisation of the multiple-nouns. In the data, 真梶 ma-kadi 'Chinese mulberry'; 御門 mi-kadwo 'the honoured gate'; and 真櫂 ma-kai 'paired oars', the prefix 真 and constituents 梶, 門 and 櫂 are temporally combined, which prevents the $\mathrm{N}_{2}$ from being voiced.

\section{Conclusion}

This study has tackled sequential voicing in Old Japanese with a focus on three matters: (a) phonologically, the interaction between the vowels and the aspirated consonants; (b) the 
association of written system and sequential voicing; and (c) the interaction between the degree of combinationality of each constituent in a multiple-noun construction and the possibility of sequential voicing. Four hundred and seventy-two data entries were examined and the following findings were reached.

(I) The compound nouns for which $\mathrm{N}_{2}$ begins with the consonant $/ \mathrm{k} /$ have the largest token number of sequential voicing; the compound nouns for which $\mathrm{N}_{2}$ begins with the consonant $/ \mathrm{p} /$ have the second largest token number (126); the compound nouns for which $\mathrm{N}_{2}$ begins with the consonant /s/ are attributed 61 tokens; and 114 tokens go to the compound nouns for which $\mathrm{N}_{2}$ begins with the consonant /t/.

(II) There were eight vowels in Old Japanese: $/ \mathrm{a} /, / \mathrm{e}_{1} /, / \mathrm{e}_{2} /, / \mathrm{i}_{1} /, / \mathrm{i}_{2} /, / \mathrm{o}_{1} /, / \mathrm{o}_{2} /$ and $/ \mathrm{u} /$. the interactions of these vowels and the possibilities of $\mathrm{N}_{2}$ 's initial phoneme becoming voiced are as follows.

(a) The vowel /a/ is most likely to form a compound noun for which $\mathrm{N}_{2}$ begins with the consonant $/ \mathrm{k} /, / \mathrm{p} /$ and $/ \mathrm{t} /$. It is not likely for the vowel /a/ to invite a voiced ' $/ \mathrm{s} /$-initial $\mathrm{N}_{1}$ '.

(b) $/ \mathrm{o}_{1} /$ and $/ \mathrm{o}_{2} /$ are both likely to combine with a voiced consonant $/ \mathrm{k} /$ or $/ \mathrm{t} /$ and are less likely to yield a voiced /s/.

(c) Regarding $/ e_{1} /$ and $/ e_{2} /$, the compound nouns for which $N_{1}$ ends with the vowel $/ e_{1} /$ are likely to combine with a voiced consonant; the compound nouns for which $\mathrm{N}_{1}$ ends with the vowel $/ \mathrm{e}_{2} /$ are not likely to. $/ \mathrm{e}_{1} /$ does not invite sequential voicing when forming a compound noun when $\mathrm{N}_{1}$ begins with the consonant /p/. / $\mathrm{e}_{2} /$ does not yield a sequential voicing when forming a compound noun when $\mathrm{N}_{1}$ begins with the consonant /s/.

(d) For $/ i_{1} /$ and $/ i_{2} /, N_{1}$ that ends with the vowel $/ i_{1} /$ is more likely to take a voiced consonant than $\mathrm{N}_{1}$ ending with $/ \mathrm{i}_{2} / \mathrm{k} / \mathrm{k} /$ and $/ \mathrm{t} /$ are the two consonants most likely to be voiced when forming a $\mathrm{N}-\mathrm{N}$ when $\mathrm{N}_{1}$ ends with $/ \mathrm{i}_{1} /$. No data suggests that $/ \mathrm{i}_{2} /$ would give rise to sequential voicing when forming a compound noun for which $\mathrm{N}_{1}$ begins with /p/, /s/ or/t/.

(e) $/ \mathrm{u} /$ never results in sequential voicing when forming a compound noun for which $\mathrm{N}_{1}$ begins with $/ \mathrm{s} /$.

(III) Sequential voicing also differs based on the writing system. Old Japanese has three writing systems: hentai-kanbun, 'variant Chinese'; junsei-kanbun, 'classical Chinese'; and man'yōgana. Essentially, the characters that render a voiced phoneme, an unvoiced phoneme or both a voiced and an unvoiced phoneme are saliently split.

(IV) Due to the unique writing system, Old Japanese extensively employs serial verb construction and serial noun constructions. We have thus examined the semantic relationship of $\mathrm{N}_{1}$ and $\mathrm{N}_{2}$ of compound nouns that bear sequential voicing and have arrived at six types: [Modifier $-\mathrm{N}_{2}$ ]; [Possession - $\mathrm{N}_{2}$ ]; [Cause - $\mathrm{N}_{2}$ ]; [Subject-object]; [Verb-object]; $\mathrm{N}_{1}$ and $\mathrm{N}_{2}$ are reduplicated words.

The most frequent relationship of $\mathrm{N}_{1}$ and $\mathrm{N}_{2}$ is [Modifier $-\mathrm{N}_{2}$ ], which is explained by the combination of [a modifier and a noun] being tighter than other combinations such as 


\section{IIMacrothink}

International Journal of Linguistics

ISSN 1948-5425

2020, Vol. 12, No. 5

[Subject-object] or [Verb-object]. We thus contend that sequential voicing has to do with the combinationality of the multiple constituents. If the first constituent acts as a prefix , sequential voicing will not be invited.

\section{References}

Lyman, B. S. (1894). The change from surd to sonant in Japanese compounds. Papers of the oriental club.

Frellesvig, B. (2010). A history of the Japanese language. Cambridge University Press.

Haruhiko, K. (1976). Rendaku no Kai (Notes on sequential voicing). Sophia Linguistica II .

Haruo, K. (1999). Nihongo no Onsee (Japanese phonetics). Tokyo: Iwanami Press.

Jianhui, L. (2014). A historical study on the sequential voicing in regard with Sino-Japanese: a focus upon the [ san] type. The Bulletin of Graduate School of Social Science (p. 37), Okayama University.

Michiaki, T. (2001). The phonetic probability of sequential voicing. Kazama Press.

Mitsuo, O. (1980). Rendaku. Sequential voicing, The Japanese dictionary. Tokyodoo.

Norinaga, M. (1767-1798). Kojiki. The Chikuma Press.

Satoshi, O. (1998). On the transition of phonetics. In H. Kubozono, \& S. OHta (Eds.), The phonetic construction and accent, volume II: Phonetic process and phonetic construction. Kenkyuusha Press.

Shigeharu, S. (1972). Heean Insee Jidai ni okeru Wago no Rendaku nitsuite: Kanchiinhon Meegisyoo. Journal of Japanese Language and Culture, 41-46.

Takeshi, M. (1977). The tendency of sequential voicing: suggestions from the Japanese-Portuguese Dictionary (p. 108). Kokugoogaku.

Yamato, S. (1989). The rules of accent and sequential voicing in compound words. In S. Miyoko (Ed.), Japanese phonetics and phonology I. Meijishoin.

Yoshinori, Y. (1988). On the compound words in Old Japanese: a focus upon sequential voicing. Journal of Japanese Linguistics, 5-7.

Yukio, O. (1980). Some Aspects of Rendaku in Japanese and Related Problems. In A. Farmer, \& Y. Otsu (Eds.), Theoretical Issues in Japanese Linguistics. MIT Working Papers, Linguistics Department of Linguistics and Philosophy Cambridge Massachusetts.

\section{Note}

Note 1. Three lexical strata coexist in Modern Japanese, i.e. native (wago), Sino-Japanese and loanwords. 
Appendix

\begin{tabular}{|c|c|c|}
\hline $\mathrm{N} 2$ & $\mathrm{~N}-\mathrm{N}$ & The ending of N1 \\
\hline kami & koto+gami & o1 \\
\hline kamo & asi+gamo & i1 \\
\hline kane & ku+gane & \\
\hline kani & asi+gani & i1 \\
\hline kapa & wo+gapa & $\mathrm{o} 2$ \\
\hline kapi & kaki+gapi & i1 \\
\hline kapi & kwopwiwasure+gapi & e1 \\
\hline kapi & wasure+gapi & e1 \\
\hline kapi & yama+gapi & \\
\hline kapo & asa+gapo & \\
\hline kara & ina+gara & \\
\hline kara & para+gara & \\
\hline kara & pisi+gara & \\
\hline kata & sasara+gata & \\
\hline kaya & taka+gaya & \\
\hline ke & kusi+ge & i1 \\
\hline kokoro & two+gokoro & $\mathrm{o} 2$ \\
\hline komo & ma-wo+gomo & 02 \\
\hline komo & tatu+gomo & \\
\hline koro & koro+goro & o1 \\
\hline koro & tukwi+goro & $\mathrm{i} 2$ \\
\hline koromo & sa+goromo & \\
\hline koromo & sita+goromo & \\
\hline koromo & tokiarapi+goromo & $\mathrm{i} 2$ \\
\hline koti & koti+goti & i1 \\
\hline koto & ipye+goto & $\mathrm{e} 2$ \\
\hline koto & katari+goto & i1 \\
\hline koto & koto+goto & o1 \\
\hline koto & pito+goto & o1 \\
\hline koto & yo+goto & o1 \\
\hline kuma & mi+guma & i1 \\
\hline kumo & sita+gumo & \\
\hline kupa & nipi+gupa & $\mathrm{i} 2$ \\
\hline kupa & ura+gupa & \\
\hline kupi & wi+gupi & $\mathrm{i} 2$ \\
\hline kuri & mitu+guri & \\
\hline kusa & ayamye+gusa & $\mathrm{e} 2$ \\
\hline kusa & momoyo+gusa & o1 \\
\hline kusa & netukwo+gusa & $\mathrm{o} 2$ \\
\hline
\end{tabular}




\begin{tabular}{|c|c|c|}
\hline kusa & nikwo+gusa & $\mathrm{o} 2$ \\
\hline kusa & uwe+gusa & $\mathrm{e} 1$ \\
\hline kusi & kotona+gusi & \\
\hline kusi & we+gusi & e1 \\
\hline kutu & uke+gutu & e1 \\
\hline kwiri & asa+gwiri & \\
\hline kwiri & yupu+gwiri & \\
\hline kwo & mana+gwo & \\
\hline kwo & waku+gwo & \\
\hline kwoma & aka+gwoma & \\
\hline kwopwi & sita+gwopwi & \\
\hline pa & momiti+ba & i1 \\
\hline pa & sasa+ba sasa+pa & \\
\hline pa & sita+ba & \\
\hline pa & ti+ba & i1 \\
\hline pa & ura+ba & \\
\hline pa & yaswo+ba & $\mathrm{o} 2$ \\
\hline paka & kari+baka & i1 \\
\hline pana & kapo+bana & o1 \\
\hline pana & sayuri+bana & i1 \\
\hline pana & sakura+bana $\sim$ sakura+pana & \\
\hline pana & wo+bana & $\mathrm{o} 2$ \\
\hline papaki & tama+bapaki & \\
\hline para & matu+bara & \\
\hline para & wakakurusu+bara & \\
\hline pasira & mana+basira & \\
\hline pasira & miya+basira & \\
\hline pata & kana+bata & \\
\hline patisu & pana+batisu & \\
\hline pi & usura+bi & \\
\hline piro & pa+biro & \\
\hline piru & nwo+biru & $\mathrm{o} 2$ \\
\hline pito & ipye+bito & $\mathrm{e} 2$ \\
\hline pito & puna+bito & \\
\hline pito & sakari+bito & i1 \\
\hline pito & satwo+bito & 02 \\
\hline pito & yama+bito & \\
\hline pito & yamasapa+bito & \\
\hline poso & pipa+boso & \\
\hline $\mathrm{pu}$ & $\mathrm{ya}+\mathrm{pu} \sim \mathrm{ya}+\mathrm{bu}$ & \\
\hline puki & yama+buki & \\
\hline pukurwo & pari+bukurwo & i1 \\
\hline
\end{tabular}




\begin{tabular}{|c|c|c|}
\hline pukurwo & suri+bukurwo & i1 \\
\hline pune & ama+bune & \\
\hline pune & opo+bune & o1 \\
\hline pune & turi+bune & i1 \\
\hline pune & wo+bune & 02 \\
\hline pusuma & kwo+busuma & 02 \\
\hline pusuma & madara+busuma & \\
\hline pusuma & musi+busuma & i1 \\
\hline pusuma & taku+busuma & \\
\hline pwi & sita+bwi & \\
\hline $\mathrm{se}$ & watari+ze & i1 \\
\hline sirwo & ne+zirwo & e1 \\
\hline ta & yama+da & \\
\hline ta-suki & putwo+dasuki & 02 \\
\hline take & ikumi+dake & i1 \\
\hline take & tasimi+dake & i1 \\
\hline take & uwe+dake & $\mathrm{e} 2$ \\
\hline take & yo+dake & o1 \\
\hline tama & aka+dama & \\
\hline tama & ana+dama & \\
\hline $\operatorname{tana}$ & puna+dana & \\
\hline tate & wo+date & o1 \\
\hline te & koromo+de & o1 \\
\hline te & matama+de & \\
\hline te & sakwi+de & i2 \\
\hline te & tama+de $\sim$ tama+te & \\
\hline $\mathrm{ti}$ & asa+di & \\
\hline $\mathrm{ti}$ & wo+di & 02 \\
\hline toko & ywo+doko & 02 \\
\hline tomo & kwo+domo & 02 \\
\hline tori & miyakwo+dori & o2 \\
\hline tori & moti+dori & i1 \\
\hline tori & mye+dori & $\mathrm{e} 2$ \\
\hline tori & na+dori & \\
\hline tori & nipo+dori ( nipo+tori) & o1 \\
\hline tori & opowoso+dori & o1 \\
\hline tori & pamasu+dori & \\
\hline tori & su+dori & \\
\hline tori & ti+dori ti+tori & i1 \\
\hline tori & wa+dori & \\
\hline tori & wosi+dori & i1 \\
\hline tori & yasaka+dori & \\
\hline
\end{tabular}




\begin{tabular}{lll}
\hline tori & yama+dori & \\
\hline tu & komori+du & i1 \\
\hline tukasa & nwo+dukasa & o2 \\
\hline tuki & saka+duki & \\
\hline tuku-ywo & yupu+dukuywo & \\
\hline tuma & oku+duma & \\
\hline tuma & omopi+duma & i2 \\
\hline tuma & ono+duma & o1 \\
\hline tuma & pana+duma & \\
\hline tuma & pasi+duma & i1 \\
\hline tuwe & tatuka+duwe & \\
\hline two & ne+dwo & e1 \\
\hline two & tati+dwo & $\mathrm{i} 1$ \\
\hline
\end{tabular}

\section{Copyrights}

Copyright for this article is retained by the author(s), with first publication rights granted to the journal.

This is an open-access article distributed under the terms and conditions of the Creative Commons Attribution license (http://creativecommons.org/licenses/by/4.0/) 